\title{
Attitudes of Montenegrin Consumers Toward Advertising Through Sport Among the Question How Often Consumers Purchase Sporting Goods
}

\author{
Gorica Zoric, Bojan Masanovic and Jovan Gardasevic \\ University of Montenegro, Faculty for Sport and Physical Education, Niksic, Montenegro
}

\begin{abstract}
A B S T R A C T
Unlike other advertising mediums such as TV commercials or online advertising, people involuntarily receive sport advertisements; they prefer to watch the game for the sporting action than the regular advertisements. However, it is important to analyse their general attitudes among various questions, mostly due to the reason it varies from demographic group to demographic group. Hence, this research was aimed at gaining relevant knowledge about the attitudes of Montenegrin consumers toward advertising through sport among the question how often consumers purchase sporting goods. The sample included 342 respondents, divided into six subsample groups: consumers who do not purchase sport goods at all, then consumers who purchase sport goods less than ones a month, next 1-3 a month, 4-6 a month, 7-9 a month, as well as consumers who purchase sport goods more than 10 times a month. The sample of variables contained the system of three general attitudes which were modelled by seven-point Likert scale. The results of the measuring were analysed by multivariate analysis (MANOVA) and univariate analysis (ANOVA) and Post Hoc test.Based on the statistical analyses it was found that significant differences occur at multivariate level, as well as between all three variables at a significance level of $(p=.000)$.
\end{abstract}

Key words: Attitudes, Advertising, Sporting Goods, Montenegro

\section{Uvod}

Vodeći se činjenicom da ulaganje u reklamiranje u sportu kao dijelu korporativne marketinške strategije neprestano raste, nastala je i potreba za istraživanjima u ovoj oblasti kako bi se utvrdile najbolje perspektive (Muratović, Bjelica i Popović, 2014). Sistematsko proučavanje odnosa potrošača prema reklamiranju je ukorijenjeno u studiji Bauer-a i Greyser-a (Popović, 2011), dok je kapitalan doprinos nauci kada je reklamiranje u sportu u pitanju dao Pyun (Klačar, i Popović, 2010), koji je sproveo istraživanje u kojem je konstruisao novi model za ispitivanje odnosa potrošača prema reklamiranju u sportu i time omogućio raznim istraživačima da ispituju stavove i uvjerenja potrošača prema reklamiranju u sportu širom svijeta i upoređuju svoje zaključke. U studijama koje su istraživale stavove prema opštem reklamiranju četrdesetih i pedesetih godina prošlog vijeka, prema Bauer-u i Greyser-u (Popović, Bjelica, Jakšić, \& Georgiev, 2013; Popovic, 2015; Popović, \& Milašinović, 2016), došlo se do zaključaka da potrošači, generalno imaju pozitivne stavove. Međutim, upoređujući navedene rezultate sa novijim istraživanjima (Bjelica, i Popović, 2011; Popović, 2011b; Popović, Molnar, i Radovanović, 2011a; Popović, Matić, Milašinović, Jakšić, \& Bjelica, 2015a; Popović, Matić, Milašinović, Hadžić, Milošević, \& Bjelica, 2015b; Popović, Matić, Milašinović, Vujović, Milošević, \& Bjelica, 2015c), utvrđeno je da potrošači imaju sve više negativne stavove prema reklamiranju. Nakon određenog vremena, Shavitt i saradnici (Bjelica i Popović, 2011) su utvrdili da ispitanici u njihovoj studiji imaju mnogo pozitivnije stavove prema reklamiranju nego što je to bio slučaj u prethodnim studijama. Pretpostavljalo se da stavovi variraju kod ispitanika, budući da oni razlikuju određene vrste reklamnih poruka, a Mittal (Popovic, 2011) je utvrdio da imaju mnogo negativnije stavove prema reklamiranju na televiziji u poređenju sa opštim reklamiranjem. Sa povećanjem nega- tivnih stavova prema reklamiranju na televiziji marketari su morali osmisliti način kako da povrate povjerenje gledalaca kada je reklamiranje na televiziji u pitanju, a to su učinili na taj način što su počeli primjenjivati nove tehnološke izume kao što su video rekorderi koji su nezainteresovanim gledaocima za reklamne poruke omogućavali da preskoče djelove koji im nijesu bili interesantni (Bjelica, Popović, Jakšić, Hadžić, \& Akpinar, 2014b; Bjelica, \& Popović, 2015a; Bjelica, \& Popović, 2015b; Bjelica, Gardasevic, Vasiljevic, \& Popovic, 2016a; Bjelica, Gardašević, Vasiljević, \& Popović, 2016c). Uporedo sa navedenim izumom, stavovi prema reklamiranju u sportu su, ponovo postali mnogo pozitivniji. Međutim, ovaj izum nije omogućavao gledaocima da preskoče dio programa sa reklamnim porukama kada je praćenje sportskih događaja u pitanju, budući da su se oni odvijali u trenutku vremena. Ipak, bliskost i privrženost sportu i sportskim subjektima su, vremenom nadvladale negativne stavove gledalaca koje su oni imali kada je opšte reklamiranje u pitanju i dovele do toga da reklamiranje u sportu zauzme mjesto koje mu danas pripada. Samim tim se postavilo i pitanje, kako kupovina sportskih proizvoda utiče na stavove potrošača prema reklamiranju u sportu kao jedan od niza problema sa kojim se nije susrećalo mnogo autora do sada (Bjelica, Popovic, \& Akpinar, 2014a; Bjelica, Popovic, \& Akpinar, 2015c; Bjelica, Popovic, \& Akpinar, 2016b; Bjelica, Popovic, \& Akpinar, 2017; Zoric, Masanovic, \& Gardasevic, 2017), a to upravo i jeste cilj ove studije.

\section{Metod}

Populaciju u ovoj studiji su činili studenti sa Univerziteta Crne Gore koji su, u vrijeme anketiranja, imali boravište na teritoriji Crne Gore, dok je uzorak ispitanika organizovan putem kombinovanja ili raslojavanja, tako da su obrađena različita svojstva navedene 
populacije i različiti prostori na kojima je ona egzistirala.

Upitnici su distribuirani studentima osnovnih studija u štampanom i elektronskom obliku. Ukupno je prikupljeno 349 upitnika, ali je 7 upitnika bilo isključeno iz analize, budući da nisu bili adekvatno popunjeni, tako da je $\mathrm{u}$ istraživanju učestvovalo, ukupno 342 ispitanika (slučajno odabranih studenta sa Univerziteta Crne Gore). Instrument istraživanja je predstavljao standardizovani upitnik (Popović, 2011) i sastojao se iz dva dijela, generalnih stavova prema reklamiranju u sportu i socio-demografskih karakteristika ispitanika kada je učestalost kupovine sportskih proizvoda tokom mjeseca u pitanju. Sistem promjenljivih u ovom upitniku je sadržao tri tvrdnje koje su ispitanici trebali da ocijene prema sedmo-stepenoj Likertovoj skali vrijednosti, kao i šest socio-demografskih karakteristika ispitanika (uopšte ne kupuju, manje od jednom mjesečno, 1-3 puta mjesečno, 4-6 puta mjesečno, 7-9 puta mjesečno, i više od 10 puta mjesečno). Popunjavanje upitnika nije trajalo, u prosjeku više od 10 minuta a ispitanici su u anketi učestvovali na dobrovoljnoj osnovi. Važno je naglasiti da je anketa bila anonimna i da su svi odgovori bili strogo poverljivi. Vrijedno je napomenuti i da su ispitanici, i pored svega navedenog imali mogućnost da $u$ svakom momentu opozovu svoje učešće u anketi, ali se niko od njih nije na tako nešto odlučio.

Empirijski podaci su analizirani putem statističkog paketa za društvene nauke (SPSS 20.0), a kao prvi korak, bila je primijenjena deskriptivna statistika kojom su izračunati, prije svega frekvencija, zatim aritmetička sredina, standardna devijacija, kao i mjere asimetrije (Skewness) i spljoštenosti (Kurtosis) za svaku od tvrdnji. Budući da su se promjenljive u ovoj studiji nalazile na naparametrijskim skalama, radi detaljnijih analiza koje su slijedile, bilo je neophodno da se one, primjenom Blomovog postupka, transformišu u skale višeg reda. Zatim su primjenom multivarijatne analize varijanse (MANOVA), univarijatne analize varijanse (ANOVA) i LSD Post Hoc testa utvrđene razlike u generalnim stavovima ispitanika prema reklamiranju u sportu u odnosu na učestalost bavljenja sportskim aktivnostima tokom mjeseca.

\section{Rezultati}

U prvoj tabeli su prikazani deskriptivni statistički podaci za sve tri tvrdnje koje su se odnosile na generalne stavove ispitanika prema reklamiranju u sportu. Prije svega, prikazana je arit-

Tabela 1. Generalni stavovi prema reklamiranju u sportu

\begin{tabular}{lcccccc}
\hline & \multirow{2}{*}{ Mean } & \multirow{2}{*}{ S.D. } & \multicolumn{2}{c}{ Skewness } & \multicolumn{2}{c}{ Kurtosis } \\
\cline { 4 - 7 } & & & Statistic & S.E. & Statistic & S.E. \\
\hline GSS1 & 5.09 & 1.642 & -.549 & .132 & -.546 & .263 \\
GSS2 & 5.51 & 1.506 & -.711 & .132 & -.468 & .263 \\
GSS3 & 5.69 & 1.693 & -.389 & .132 & -.545 & .263 \\
\hline
\end{tabular}

Legenda: Mean - Aritmetička sredina; S.D. - Standardna devijacija; Skewness - Mjera asi-
metrije; Kurtosis - Mjera spljoštenosti; Statistic - Statistička vrijednost; S.E. - Standardna greška; GSS1 - Moje opšte mišljenje je naklonjeno reklamiranju u sportu; GSS2 - Sveobuhvatno, smatram da je reklamiranje u sportu dobra stvar; GSS3 - Sveobuhvatno, da li ne volite ili volite reklamiranje u sportu

metička sredina koja oslikava pozitivne vrijednosti stavova kada su sve tri tvrdnje u pitanju, dok vrijednosti standardne devijacije pokazuju da elementi skupa, u prosjeku ne odstupaju značajno od aritmetičke sredine. Kada se govori o mjerama asimetrije (Skewness) i spljoštenosti (Kurtosis), negativne vrijed- nosti asimetrije kod svih promjenljivih pokazuju da je većina rezultata desno od srednje vrijednosti, među većim vrijednostima,dok negativne vrijednosti spljostenosti kod svih promjenljivih pokazuje da je raspodjela pljosnatija od normalne tj. da ima više rezultata nagomilanih na repovima raspodjele.

Tabela 2. Multivarijatna značajnostrazlika u sistemu generalnih stavova prema reklamiranju u sportu kod ispitanika sa različitim navikama kada je kupovina sportskih proizvoda u pitanju

\begin{tabular}{llccc}
\hline & & N & Mean & S.D. \\
\hline GSS1 & Ne kupuju & 10 & 4.00 & 2.108 \\
& $<1$ & 106 & 4.94 & 1.672 \\
$1-3$ & 168 & 5.29 & 1.448 \\
& $4-6$ & 22 & 4.55 & 1.969 \\
& $7-9$ & 16 & 6.00 & 1.265 \\
& $>10$ & 20 & 4.60 & 2.113 \\
& Ukupno & 342 & 5.09 & 1.642 \\
\hline GSS2 & Ne kupuju & 10 & 5.40 & 1.075 \\
& $<1$ & 106 & 5.28 & 1.578 \\
& $1-3$ & 168 & 5.73 & 1.370 \\
& $4-6$ & 22 & 4.91 & 1.770 \\
& $7-9$ & 16 & 6.12 & 1.310 \\
& $>10$ & 20 & 5.10 & 1.861 \\
& Ukupno & 342 & 5.51 & 1.506 \\
\hline GSS3 & Ne kupuju & 10 & 3.20 & 1.398 \\
& $<1$ & 106 & 4.74 & 1.725 \\
& $1-3$ & 168 & 4.89 & 1.645 \\
& $4-6$ & 22 & 3.91 & 1.974 \\
& $7-9$ & 16 & 4.38 & 1.708 \\
& $>10$ & 20 & 4.60 & 1.142 \\
& Ukupno & 342 & 4.69 & 1.693 \\
\hline
\end{tabular}

$\mathrm{F}=0.880 ; \mathrm{p}=.000$ 
Tabela 3. Univarijatna značajnostrazlika u sistemu generalnih stavova prema reklamiranju u sportu kod ispitanika sa različitim navikama kada je kupovina sportskih proizvoda u pitanju

\begin{tabular}{ccc}
\hline & F & p \\
\hline GSS1 & 3.472 & .004 \\
GSS2 & 2.786 & .018 \\
GSS3 & 3.207 & .008 \\
\hline
\end{tabular}

U nastavku ove studije su prikazani komparativni statistički podaci generalnih stavova prema reklamiranju u sportu koji su dobijeni primjenom multivarijatne analize varijanse (MANOVA), univarijatne analize varijanse (ANOVA) i LSD Post Hoc testa, a u cilju utvrđivanja razlike u generalnim stavovima ispitanika prema reklamiranju u sportu u odnosu na učestalost kupovine sportskih proizvoda.

Tabela 4. Utvrđivanje značajnih razlika u sistemu generalnih stavova prema reklamiranju u sportu primjenom Post Hoc testa između pojedinačnih entiteta sa različitim navikama kada je kupovina sportskih proizvoda u pitanjukod tvrdnje „moje opšte mišljenje je naklonjeno reklamiranju u sportu“

\begin{tabular}{cccccc}
\hline vs & Ne kupuju & $<\mathbf{1}$ & $\mathbf{1 - 3}$ & $\mathbf{4 - 6}$ & $\mathbf{7 - 9}$ \\
\hline$<1$ & .078 & & & & \\
$1-3$ & .015 & .088 & & & \\
$4-6$ & .376 & .293 & .044 & & \\
$7-9$ & .002 & .015 & .091 & .006 & \\
$>10$ & .338 & .383 & .073 & .913 & .010 \\
\hline
\end{tabular}

Inspekcijom druge tabele u kojoj su prikazani rezultati multivarijatne analize, jasno se uočava da u cijelom sistemu upoređivanih parametara postoji statistički značajna razlika u gene-

ralnih stavovima prema reklamiranju u sportu u odnosu na učestalost kupovine sportskih proizvoda $(\mathrm{p}=.000)$.

Tabela 5.Utvrđivanje značajnih razlika u sistemu generalnih stavova prema reklamiranju u sportu primjenom Post Hoc testa između pojedinačnih entiteta sa različitim navikama kada je kupovina sportskih proizvoda u pitanjukod tvrdnje

\begin{tabular}{cccccc}
\multicolumn{5}{c}{ „sveobuhvatno, smatram da je reklamiranje u sportu dobra stvar“ } \\
\hline vs & Ne kupuju & $<\mathbf{1}$ & $\mathbf{1 - 3}$ & $\mathbf{4 - 6}$ & $\mathbf{7 - 9}$ \\
\hline$<1$ & .812 & & & & \\
$1-3$ & .501 & .017 & & & \\
$4-6$ & .387 & .284 & .016 & & \\
$7-9$ & .227 & .035 & .306 & .013 & \\
$>10$ & .603 & .614 & .076 & .678 & .041 \\
\hline
\end{tabular}

Inspekcijom treće tabele u kojoj su prikazani rezultati univarijatne analize, jasno se uočava da je, takođe došlo do statistički značajnih razlika u generalnim stavovima prema reklami- ranju u sportu u odnosu na učestalost kupovine sportskih proizvoda kod sve tri promjenljive.

Tabela 6.Utvrđivanje značajnih razlika u sistemu generalnih stavova prema reklamiranju u sportu primjenom Post Hoc testa između pojedinačnih entiteta sa različitim navikama kada je kupovina sportskih proizvoda u pitanju kod tvrdnje

\begin{tabular}{cccccc}
\multicolumn{5}{c}{ „Sveobuhvatno, da li ne volite ili volite reklamiranje u sportu“" } \\
\hline vs & Ne kupuju & $<\mathbf{1}$ & $\mathbf{1 - 3}$ & $\mathbf{4 - 6}$ & $\mathbf{7 - 9}$ \\
\hline$<1$ & .006 & & & & \\
$1-3$ & .002 & .448 & & & \\
$4-6$ & .265 & .035 & .010 & & \\
$7-9$ & .081 & .420 & .236 & .395 & \\
$>10$ & .031 & .738 & .458 & .180 & .687 \\
\hline
\end{tabular}

Inspekcijom naredne tri tabele gdje su prikazani rezultati Post Hoc testa koji ukazuju na značajnost razlika između parova pojedinačnih entiteta sa različitim navikama kada je kupovina sportskih proizvoda u pitanju za svaku promjenljivu, budući na rezultate koji su se pojavili na univarijatnom nivou, očekivano se uočava da postoje statistički značajne razlike pojedinih parametara.

Došlo se do zaključka da se kod prve tvrdnje „,moje opšte mišljenje je naklonjeno reklamiranju u sportu“ javljaju razlike između ispitanika koji kupuju sportske proizvode između 7-9 puta mjesečno i većine ostalihgrupa; između ispitanika koji kupuju sportske proizvode između 1-3 puta mjesečno i grupa koje sportske proizode ne kupuje uopšte i između 4-6 puta. Takođe i između onih grupa koje kupuju sportske proizvode više od 10 puta i između 7-9 puta mjesečno. Možemo uočiti najmanje pozitivnih rezultata kod grupe koja ne kupuje sportske proizvode.

Došlo se do zaključka da se kod druge tvrdnje „,sveobuhvatno, smatram da je reklamiranje u sportu dobra stvar" javljaju razlike između ispitanika koji kupuju sportske proizvode između 1-3 puta mjesečno i grupa koje kupuju sportske proizvode manje od jednom i između 4-6 puta mjesečno. Takođe i između ispitanika koji kupuju sportske proizvode između 7-9 puta mjesečno i grupa koje sportske proizode kupuju manje od jednom, 4-6 puta i preko 10 puta mjesečno.

Došlo se do zaključka da se kod treće tvrdnje „,sveobuhvatno, da li ne volite ili volite reklamiranje u sportu“ pojavljuju razlike prije svega između ispitanika koji ne kupuju sportske proizvode i većine ostalih entiteta. Takođe između onih koji ku- 
puju sportske proizvode 4-6 puta i manje od jednom, 1-3 puta mjesečno. Možemo uočiti najmanje pozitivnih rezultata kod grupe koja ne kupuje sportske proizvode.

\section{Diskusija}

S obzirom da su rezultati pokazali da ispitanici imaju veoma pozitivan stav prema reklamiranju u sportu što potvrđuje visoka vrijednost aritmetičke sredine za sve tri promjenljive, kao i da skoro dvije trećine ispitanika imaju pozitivan stav prema reklamiranju u sportu što se ogleda u izrazito negativnim vrijednostima mjera asimetrije, trebalo bi naglasiti da su ovi rezultati usaglašeni sa rezultatima prethodnih istraživanja (Molnar, Lilić, Popović, Akpinar, \& Jakšić, 2011; Popović, Jakšić, Matić, Bjelica, \& Maksimović, 2014; Popović, Bjelica, Georgiev, \& Akpinar, 2011b; Popović, Matić, Milašinović, Jakšić, \& Bjelica, 2015d; Popović, Matić, Milašinović, Hadžić, Milošević, \& Bjelica, 2015e; Popović, Matić, Milašinović, Vujović, Milošević, \& Bjelica, 2015f; Popović, Jakšić, Matić, Bjelica, \& Maksimović, 2015g; Masanovic, Zoric, \& Gardasevic, 2017; Gardasevic, Zoric, \& Masanovic, 2017), i da ne postoje značajne razlike koje bi trebalo pomenuti. Dobijeni rezultati, takođe jasno ukazuju da ispitanici koji žive na različitim lokacijama, kao što su Sjedinjene države, Turska, Crna Gora i Srbiji, imaju pozitivne stavove prema reklamiranju u sportu, dok je, ipak, poređenja radi, vrijedno navesti da, prema Mittal-u (Bjelica i sar., 2016a; Bjelica i sar., 2016c), različite studije ukazuju na negativne stavove

\section{R E F E R E N C E S}

Bjelica, D. i Popović, S. (2011). Stavovi potrošača prema reklamiranju u sportu u odnosu na učestalost posmatranja sportskih događaja. Sportske nauke i zdravlje, 1(2), 114-119.

Bjelica, D., Popovic, S., \&Akpinar, S. (2014a). Book of Abstracts of the 11th International Scientific Conference on Transformation Process in Sport "Sport Performance". Podgorica: Montenegrin Sports Academy.

Bjelica, D., Popović, S., Jakšić, D., Hadžić, R., \& Akpinar, S. (2014b). How Does Advertising through Sport Work? Evidence from Turkey. In Proceedings book of the 7th International Scientific Conference on Kinesiology "Fundamental and Applied Kinesiology - Steps Forward " (477). Opatija: University of Zegreb, Faculty of Kinesiology.

Bjelica, D., \& Popović, S. (2015a). Evolucija reklamiranja sa posebnim osvrtom na reklamiranje u sportu. Sport Mont, 13(43,44,45), 35-41.

Bjelica, D., \& Popović, S. (2015b). Evolution of Advertising with a Specific Retrospection at Sport Advertising. In Book of Abstracts of the 12th International Scientific Conference on Transformation Process in Sport "Sport Performance" (60-61), Podgorica: Montenegrin Sports Academy.

Bjelica, D., Popovic, S., \&Akpinar, S. (2015c). Book of Abstracts of the 12th International Scientific Conference on Transformation Process in Sport "Sport Performance". Podgorica: Montenegrin Sports Academy.

Bjelica, D., Gardasevic, J., Vasiljevic, I., \& Popovic, S. (2016a). Ethical Dilemmas of Sport Advertising. Sport Mont, 14(3), 41-43.

Bjelica, D., Popovic, S., \&Akpinar, S. (2016b). Book of Abstracts of the 13th International Scientific Conference on Transformation Process in Sport "Sport Performance". Podgorica: Montenegrin Sports Academy.

Bjelica, D., Gardašević, J., Vasiljević, I., \&Popović, S. (2016c). kada je reklamiranje proizvoda $\mathrm{u}$ tradicionalnim industrijama $\mathrm{u}$ pitanju. Prema tome, više je nego evidentno da je primjena sporta u savremenoj poslovnoj komunikaciji uticala da se generalni stavovi potrošača značajno promijene kada je reklamiranje u pitanju, a prepoznavanje privlačnosti sporta je omogućilo poslovnim organizacijama da se približe sportskim potrošačima i na mnogo bezbolniji način utiču na njihovo ponašanje.

Utvrđivanjem razlike u generalnim stavovima ispitanika prema reklamiranju u sportu u odnosu na učestalost kupovine sportskih proizvoda, u ovoj studiji su pronađene razlike u stavovima između ispitanika koji imaju različite navike kada je kupovina sportskih proizvoda u pitanju. Kod promjenljivih „moje opšte mišljenje je naklonjeno reklamiranju u sportu“, i ,sveobuhvatno, smatram da je reklamiranje u sportu dobra stvar“, uočavamonajmanje pozitivnih rezultata kod grupe koja ne kupuje sportske proizvode. Dok kod promjenjive „sveobuhvatno, da li ne volite ili volite reklamiranje u sportu“. Možemo uočiti da je najmanje pozitivnih rezultata kod grupe koja kupuje sportske proizvode 4-6 puta mjesečno.

$\mathrm{Na}$ osnovu statističkih analiza, utvrđeno je da se značajne razlike javljaju na multivarijatnom nivou, kao i između jedne varijable na univerijatnom nivou značajnosti od $p=.05$. Buduća istraživanja bi trebalo usmjeriti na veći broj ispitanika, budući da se značajan broj ispitanika grupiše u kategoriji sa manjim brojem kupovine sportskih proizvoda tokom mjeseca, posebno iz razloga što se očekuje da bi neke razlike mogle biti interesantne i korisne kako za teoriju tako i za praksu.

Ethical dilemmas of sport advertising. In Book of Abstracts of the 13th International Scientific Conference on Transformation Process in Sport "Sport Performance" (41), Podgorica: Montenegrin Sports Academy.

Bjelica, D., Popovic, S., \&Akpinar, S. (2017). Book of Abstracts of the 14th International Scientific Conference on Transformation Process in Sport "Sport Performance". Podgorica: Montenegrin Sports Academy.

Gardasevic, J., Zoric, G., \& Masanovic, B. (2017). Attitudes of Turkish consumers toward advertising through sport among the question how often they participate in sports activities. Journal of Anthropology of Sport and Physical Education, 1(1), 23-27. doi: 10.26773/jaspe.171004

Klačar, M. iPopović, S. (2010). Reklamiranje u sportukaoefektivnosredstvosavremenekomunikacije. Teme, 4, 12191230.

Masanovic, B., Zoric, G., \& Gardasevic, J. (2017). Attitudes of Turkish consumers toward advertising through sport among the frequency of watching sports events. Journal of Anthropology of Sport and Physical Education, 1(1), 3-7. doi: 10.26773/jaspe. 171001

Molnar, S., Lilić, Lj., Popović, S., Akpinar, S., \& Jakšić, D. (2011). Attitudes of various demographic groups toward advertising through sport at METU. Facta Universitatis, Series: Physical Education and Sport, 9(3), 255-263.

Muratović, A., Bjelica, D., \& Popović, S. (2014). Examining beliefs and attitudes toward advertising through sport among montenegrin consumers. Facta Universitatis, Series: Physical Education and Sport, 12(2), 95-104.

Popovic, S. (2011). Reklamiranje u sportu kao efektivno sredstvo savremene poslovne komunikacije. Neobjavljena doktoska disertacija, Novi Sad: Univerzitet u Novom Sadu.

Popović, S. (2011b). Stavovi potrošača prema reklamiranju u 
sportu u odnosu na učestalost kupovine sportskih proizvoda. Sport Mont, 9(28,29,30), 140-147.

Popović, S., Molnar, S. i Radovanović, D. (2011a). Stavovi potrošača prema reklamiranju u sportu u odnosu na učestalost bavljenja sportskim aktivnostima. Sport Mont, 9(28,29,30), 148-155.

Popović, S., Bjelica, D., Georgiev, G., \& Akpinar, S. (2011b). Comparison of attitudes toward advertising through sport between Montenegrin and Turkish stakeholders. In Proceedings book of the 6th International Scientific Conference on Kinesiology "Integrative Power of Kinesiology" (612). Opatija: University of Zegreb, Faculty of Kinesiology.

Popović, S., Jakšić, D., Matić, R., Bjelica, D., \& Maksimović, N. (2014). Examining Beliefs and Attitudes toward Advertising through Sport among Serbian Consumers. In Book of abstracts of International conference "Economics and Management of Sports 2014” (pp. 11-12). Brno: Faculty of Sports Studies.

Popović, S., Bjelica, D., Jakšić, D, \& Georgiev, G. (2013). How does Advertising Through Sport Work? Evidence from Montenegro. In Book of Abstracts of the $18^{\text {th }}$ Annual Congress of the European College of Sport Science (444-445), Barcelona: National Institute of Physical Education of Catalonia.

Popović, S., Matić, R., Milašinović, R., Jakšić, D., \&Bjelica, D. (2015a). Stavovi srbijanskih potrošača prema reklamiranju u sportu u odnosu na učestalost bavljenja sportskim aktivnostima. Sport Mont, 13(43,44,45), 50-56.

Popović, S., Matić, R., Milašinović, R., Hadžić, R., Milošević, Z. \&Bjelica, D. (2015b). Stavovi srbijanskih potrošača prema reklamiranju u sportu u odnosu na učestalost kupovine sportskih proizvoda. Sport Mont, 13(43,44,45), 262-269.

Popović, S., Matić, R., Milašinović, R., Vujović, D., Milošević, Z. \&Bjelica, D. (2015c). Stavovi srbijanskih potrošača prema reklamiranju u sportu u odnosu na učestalost posmatranja sportskih događaja. Sport Mont, 13(43,44,45), 270-276.
Popović, S., Matić, R., Milašinović, R., Jakšić, D., \&Bjelica, D. (2015d). Attitudes of Serbian Consumers toward Advertising through Sport among the Question How Often They Participate in Sports Activities. In Book of Abstracts of the 12th International Scientific Conference on Transformation Process in Sport "Sport Performance" (58-59), Podgorica: Montenegrin Sports Academy.

Popović, S., Matić, R., Milašinović, R., Hadžić, R., Milošević, Z., \& Bjelica, D. (2015e). Attitudes of Serbian Consumers toward Advertising through Sport among the Question How Often Consumers Purchase Sporting Goods. In Book of $A b-$ stracts of the 12th International Scientific Conference on Transformation Process in Sport "Sport Performance" (5960), Podgorica: Montenegrin Sports Academy.

Popović, S., Matić, R., Milašinović, R., Vujović, D., Milošević, Z., \& Bjelica, D. (2015f). Attitudes of Serbian Consumers toward Advertising through Sport among the Frequency of Watching Sports Events. In Book of Abstracts of the 12th International Scientific Conference on Transformation Process in Sport "Sport Performance" (60), Podgorica: Montenegrin Sports Academy.

Popović, S., Jakšić, D., Matić, R., Bjelica, D., \& Maksimović, N. (2015g). Examining Beliefs and Attitudes toward Advertising through Sport among Serbian Consumers. Studia Sportiva, 9(1), 225-231.

Popovic, S. (2015). Sport Nowadays (In Montenegrin). In D. Bjelica (Ed.), Advertising Role of Sponsorship in Modern Sport (pp. 111-116). Podgorica: Montenegrin Sports Academy.

Popović, S. \& Milašinović, R. (2016). Model of Advertising Communication in Sport. Sport Mont, 14(1), 33-38.

Zoric, G., Masanovic, B., \& Gardasevic, J. (2017). Attitudes of Turskish consumers toward advertising through sport among the question how often consumers purchase sporting goods. Journal of Anthropology of Sport and Physical Education, 1(1), 17-21. doi: 10.26773/jaspe.171003

G. Zoric

University of Montenegro, Faculty for Sport and Physical Education, Narodne omladine bb, Niksic, Montenegro e-mail: goricazoric27@gmail.com 
